\title{
SERCA2a gene transfer improves electrocardiographic performance in aged mdx mice
}

\author{
Jin-Hong Shin ${ }^{1}$, Brian Bostick${ }^{1}$, Yongping Yue ${ }^{1}$, Roger Hajjar ${ }^{2}$ and Dongsheng Duan ${ }^{1 *}$
}

\begin{abstract}
Background: Cardiomyocyte calcium overloading has been implicated in the pathogenesis of Duchenne muscular dystrophy (DMD) heart disease. The cardiac isoform of sarcoplasmic reticulum calcium ATPase (SERCA2a) plays a major role in removing cytosolic calcium during heart muscle relaxation. Here, we tested the hypothesis that SERCA2a over-expression may mitigate electrocardiography (ECG) abnormalities in old female mdx mice, a murine model of DMD cardiomyopathy.
\end{abstract}

Methods: $1 \times 10^{12}$ viral genome particles/mouse of adeno-associated virus serotype-9 (AAV-9) SERCA2a vector was delivered to 12 -m-old female $\mathrm{mdx}$ mice $(\mathrm{N}=5)$ via a single bolus tail vein injection. AAV transduction and the ECG profile were examined eight months later.

Results: The vector genome was detected in the hearts of all AAV-injected mdx mice. Immunofluorescence staining and western blot confirmed SERCA2a over-expression in the mdx heart. Untreated mdx mice showed characteristic tachycardia, PR interval reduction and QT interval prolongation. AAV-9 SERCA2a treatment corrected these ECG abnormalities.

Conclusions: Our results suggest that AAV SERCA2a therapy may hold great promise in treating dystrophindeficient heart disease.

\section{Background}

The heart is often afflicted in Duchenne muscular dystrophy (DMD), a lethal muscle disease caused by dystrophin deficiency (reviewed in [1]). Dystrophin is a large sub-sarcolemmal protein that plays a critical role in maintaining sarcolemma integrity. In a dystrophin-deficient heart, myocardial contraction results in sarcolemmal damage. Subsequent cardiomyocyte necrosis and fibrosis leads to dilated cardiomyopathy. The exact molecular mechanisms underlying dystrophin-deficient heart disease remain to be fully clarified. Interestingly, ample evidence suggests that abnormal elevation of cytosolic calcium may play a central role in the pathogenesis of DMD heart disease [2-6].

The sarcoplasmic reticulum is the primary calcium storage organelle in muscle cells. In cardiomyocytes,

\footnotetext{
*Correspondence: duand@missouri.edu

'Department of Molecular Microbiology and Immunology, School of

Medicine, The University of Missouri, Columbia, MO, USA

Full list of author information is available at the end of the article
}

removal of cytosolic calcium is mainly accomplished by the cardiac isoform of sarcoplasmic reticulum calcium ATPase (SERCA2a) via its pump activity (reviewed in [7]). Basically, SERCA2a actively transports calcium from the cytosol to the sarcoplasmic reticulum during myocardial relaxation. SERCA2a expression/activity is reduced in various forms of heart failure in experimental animal models and human patients (reviewed in $[8,9]$ ). In the heart of dystrophin-deficient mdx mice, SERCA2a expression is also significantly decreased [10]. Here, we hypothesize that intentional SERCA2a over-expression may help mitigate cytosolic calcium overload and improve cardiac electrophysiology in symptomatic $\mathrm{mdx}$ mice.

Among various gene transfer vectors, adeno-associated virus serotype-9 (AAV-9) is by far the most robust vector for transducing the mdx heart when administrated intravascularly [11-13]. We have recently established the aged female mdx mice as an authentic model of DMD cardiomyopathy $[14,15]$. To test our hypothesis, we

\section{() Biomed Central}

(c) 2011 Shin et al; licensee BioMed Central Ltd. This is an Open Access article distributed under the terms of the Creative Commons Attribution License (http://creativecommons.org/licenses/by/2.0), which permits unrestricted use, distribution, and reproduction in any medium, provided the original work is properly cited. 
delivered $1 \times 10^{12}$ viral genome $(\mathrm{vg})$ particles/mouse of AAV-9 SERCA2a vector to 12-m-old female mdx mice via a single bolus tail vein injection. Electrocardiography (ECG) was performed when mice reached 20 months of age. Compared to that of age- and gender-matched untreated mdx mice, the ECG profile of AAV-9 SERCA2a treated mdx mice was significantly improved.

\section{Methods}

\section{Recombinant AAV-9 SERCA2a vector}

The cis plasmid for AAV-9 SERCA2a vector production has been extensively characterized and used in various animal studies and human trials [16-19]. In this construct, the human SERCA2a cDNA expression was regulated by the ubiquitous cytomegalor virus (CMV) promoter, a hybrid intron and a bovine growth hormone poly-adenylation signal (Figure 1A). Experimental AAV vector was produced using a previously reported triple plasmid transfection protocol $[20,21]$. Recombinant viral stocks were purified through two rounds of isopycnic $\mathrm{CsCl}$ ultracentrifugation as we previously described [22]. Viral titration and quality control were performed according to our published protocol [22,23].

\section{In vivo gene delivery}

All animal experiments were approved by the Animal Care and Use Committee of the University of Missouri and were in accordance with NIH guidelines. Dystrophin-deficient mdx mice and normal control C57Bl/10 (BL10) mice were purchased from The Jackson Laboratory (Bar Harbor, ME). AAV-9 SERCA2a vector was injected to conscious 12 -m-old $\mathrm{mdx}$ mice in a single bolus through the tail vein according to a previously described protocol [11]. Each mouse received $1 \times 10^{12}$ vg particles of AAV-9.

\section{PCR detection of the AAV vector genome}

DNA was extracted from frozen heart tissue sections as we described before [24]. The AAV SERCA2a vector genome was amplified with a forward primer corresponding to the CMV promoter (DL1263, 5'-CCAAGTACGCCCCCTATTGA) and a reverse primer corresponding to the human SERCA2a cDNA (DL1262, 5'- AGCCCCGTACTCTCGTTGAC) (Figure 1A). The size of the expected PCR product is $519 \mathrm{bp}$. The mouse CFTR gene was used as an internal control. The forward primer corresponds to the mouse cystic fibrosis transmembrane conductance regulator (CFTR) gene exon 2 (DL1286, 5'-CATATACCAAGCCCCTTCTGCT). The reverse primer corresponds to the mouse CFTR gene intron 2 (DL1287, 5'- TGCATCACTTTTAAATGGAACCTC). The expected mouse CFTR gene amplicon size is $160 \mathrm{bp}$.

\section{Western blot}

The frozen heart was ground to fine powder in liquid nitrogen. Whole heart muscle lysate was prepared according to our published protocol [15,25]. Primary antibody of for SERCA2a $(1: 3,000)$ has been previously described [26]. A monoclonal antibody to $\beta$-actin (1:5,000, Sigma; St Louis, MO) was used to confirm protein loading.

\section{SERCA2a immunofluorescence staining}

SERCA2a expression was confirmed by immunofluorescence staining. Briefly, $10 \mu \mathrm{m}$ frozen heart sections was blocked with $20 \%$ goat serum at room temperature for $30 \mathrm{~min}$. The rabbit polyclonal anti-SERCA2a antibody was then applied at the dilution of 1:3,000 overnight at $4^{\circ} \mathrm{C}$ [26]. SERCA2a staining was revealed with an Alex 488 conjugated goat anti-rabbit antibody (1:100 dilution).

\section{Histopathology examination}

General heart histology was evaluated by hematoxylin and eosin (HE) staining. Cardiac fibrosis was examined by Masson trichrome staining as we described before [27]. Fibrotic tissue stained blue and myocardium stained dark red.

\section{ECG examination}

Mice were anesthetized with isoflurane (3\% induction, $1-1.5 \%$ maintenance). A non-invasive 12-lead ECG was performed according to our published protocol [28]. ECG signals were processed through a single channel bioamplifier (Model ML132; AD Instruments) and then recorded on a Model MLA0112S PowerLab system using the Chart software (version 5.5.5, AD Instruments, Colorado Springs, CO). ECG from a continuous $1 \mathrm{~min}$ recording was analyzed by the Chart ECG analysis software (version 2.0, AD Instruments). The amplitude of the $\mathrm{Q}$ wave was analyzed using the lead I tracing. The remaining ECG parameters were analyzed using lead II tracing results. Cardiomyopathy index is determined by dividing the QT interval with the PQ segment (QT/PQ).

\section{Statistical Analysis}

Data are presented as mean \pm standard error of mean. Statistical analysis was performed with the SPSS software (SPSS, Chicago, IL) using one-way ANOVA followed by Bonferroni post hoc analysis. Difference was considered significant when $P<0.05$.

\section{Results}

AAV-9 mediated SERCA2a gene transfer in old mdx mice To evaluate SERCA2a gene therapy in a dystrophin-deficient heart, we packaged the CMV.SERCA2a construct 


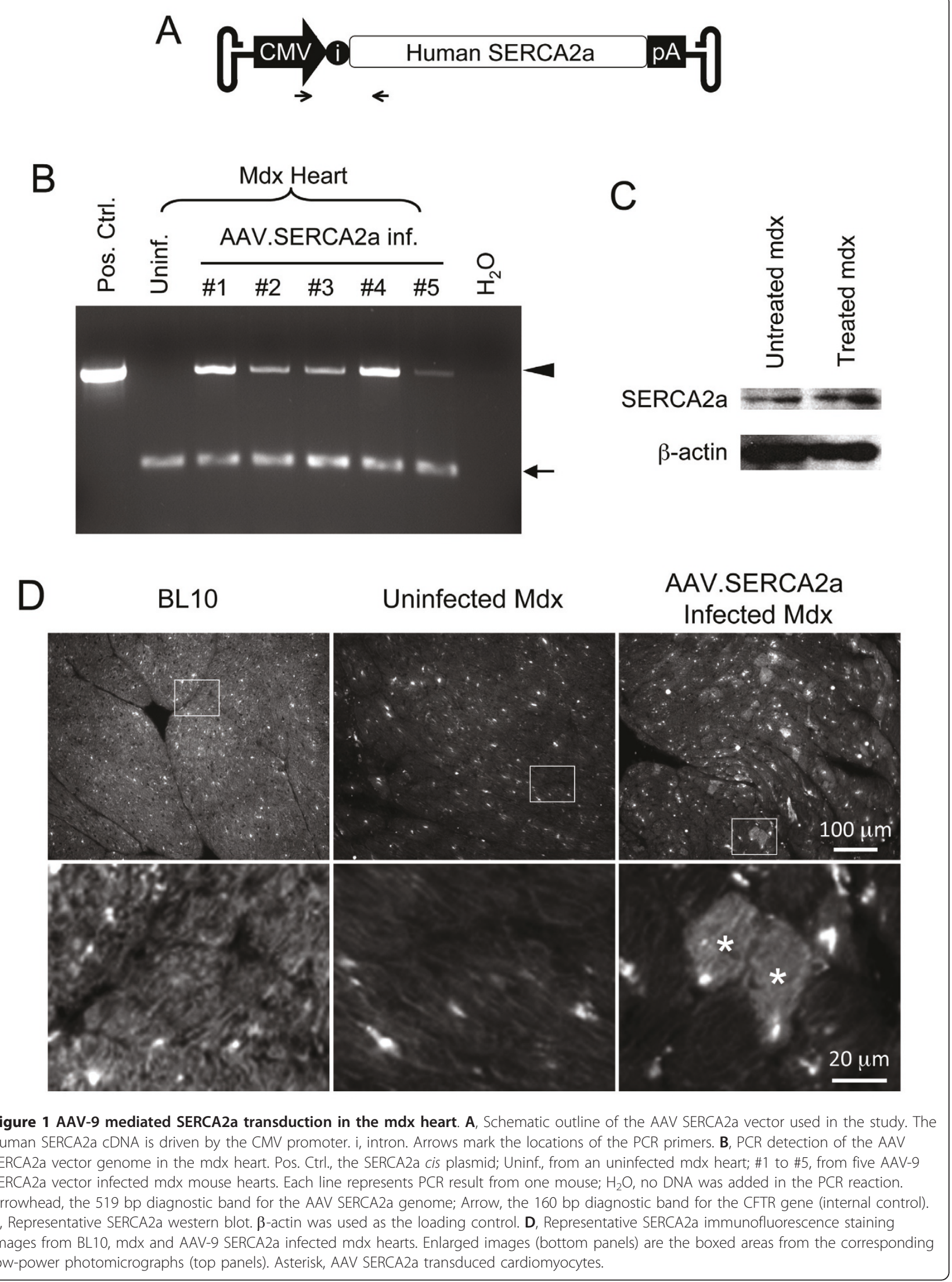


into AAV-9 (Figure 1A). Since the heart of young $\mathrm{mdx}$ mice is mildly affected, we opted to test SERCA2a therapy in 12-month-old mdx mice [29]. At this age, $\mathrm{mdx}$ mice exhibit cardiac histopathology but do not suffer heart failure [29]. The CMV.SERCA2a vector has been extensively characterized in different animal models and is currently in use in a human trial $[17-19,30,31]$. We injected AAV-9 SERCA2a to 12-m-old mdx mice via the tail vein. Eight months later, we examined the AAV genome in the heart. The vector genome was detected in all mdx mice that received AAV-9 SERCA2a injection but not in untreated mdx mice (Figure 1B). To confirm SERCA2a expression, we performed western blot and immunofluorescence staining. Compared with untreated $m d x$, increased SERCA2a expression was found in AAV infected $\mathrm{mdx}$ mice by western blot (Figure 1C). Consistent with previous reports $[10,32]$, we observed endogenous cytosolic SERCA2a staining in the BL10 heart by immunostaining (Figure 1D). Further, the endogenous SERCA2a level was reduced in the mdx heart (Figure 1D). Consistent with the published AAV-9 transduction profile in the mdx heart $[11,12]$, we observed mosaic but widespread AAV-mediated SERCA2a expression in the hearts of AAV-9 SERCA2a infected mdx mice (Figure 1D).

\section{AAV-9 SERCA2a therapy improved ECG performance}

On histopathologic examination, the hearts of SERCA2a treated mice were not different from those of untreated mdx mice (Figure 2). Myocardial fibrosis was clearly observed in the hearts of both treated and untreated mdx mice (Figure 2). Surprisingly, ECG examination revealed significant improvement (Figure 3). Specifically, tachycardia was corrected. The PR interval, QT interval and cardiomyopathy index were normalized (Figure 3B). Interestingly, the widened QRS duration and the deep Q wave were not improved (Figure 3B).

\section{Discussion}

Cardiac complications are a major health issue in DMD. Current treatments are limited to symptomatic medications and heart transplantation [33]. In an effort to develop more effective therapies, several experimental gene therapy approaches have been explored in the rodent models [29]. These include AAV-mediated expression of an abbreviated synthetic dystrophin gene and antisense oligonucleotides-mediated exon skipping $[12,13,34-36]$. In general, the goal of these strategies is to express a truncated yet functional dystrophin protein. While these attempts are highly encouraging, a recent clinical trial suggests that immunity to dystrophin may

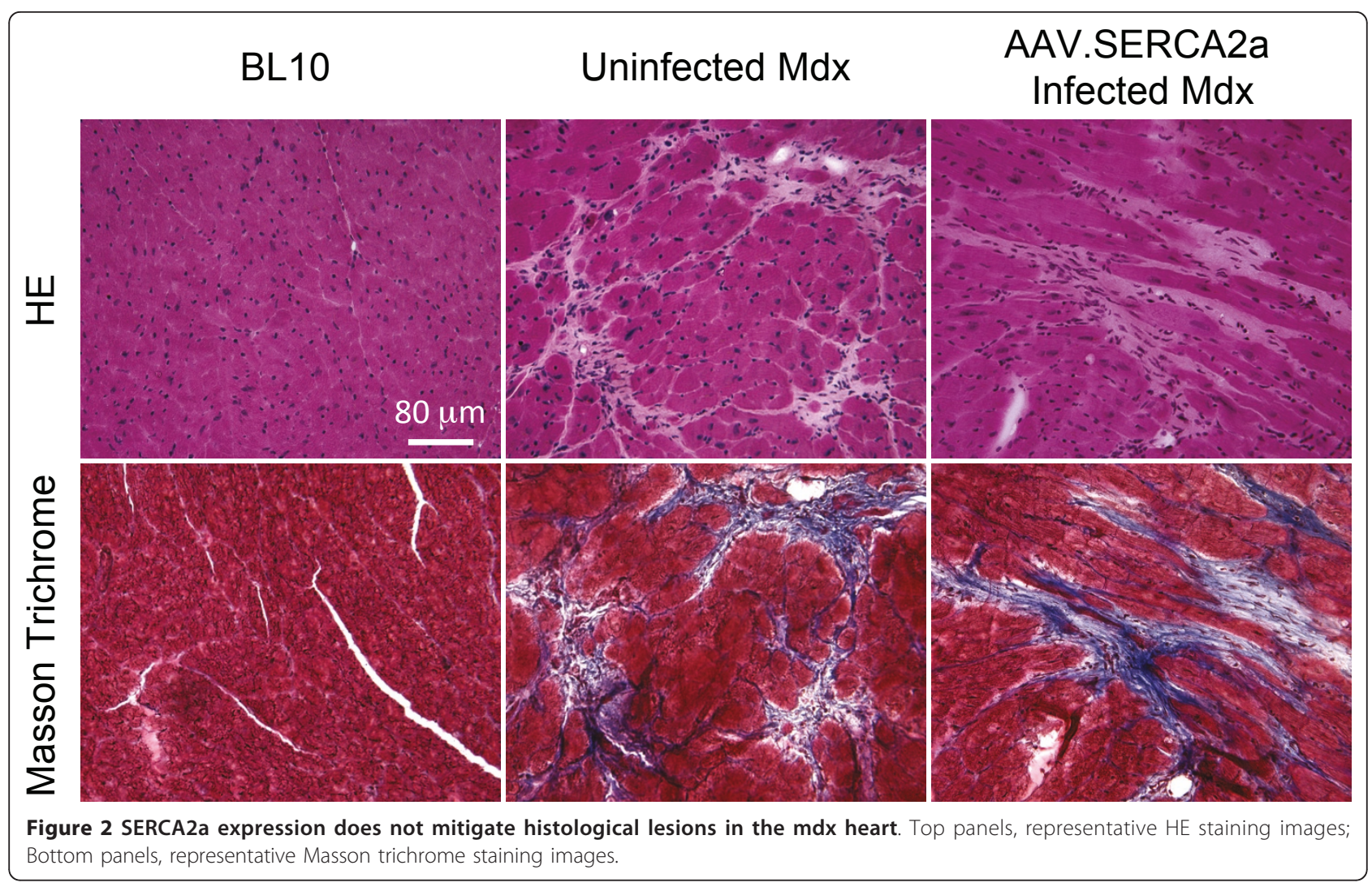




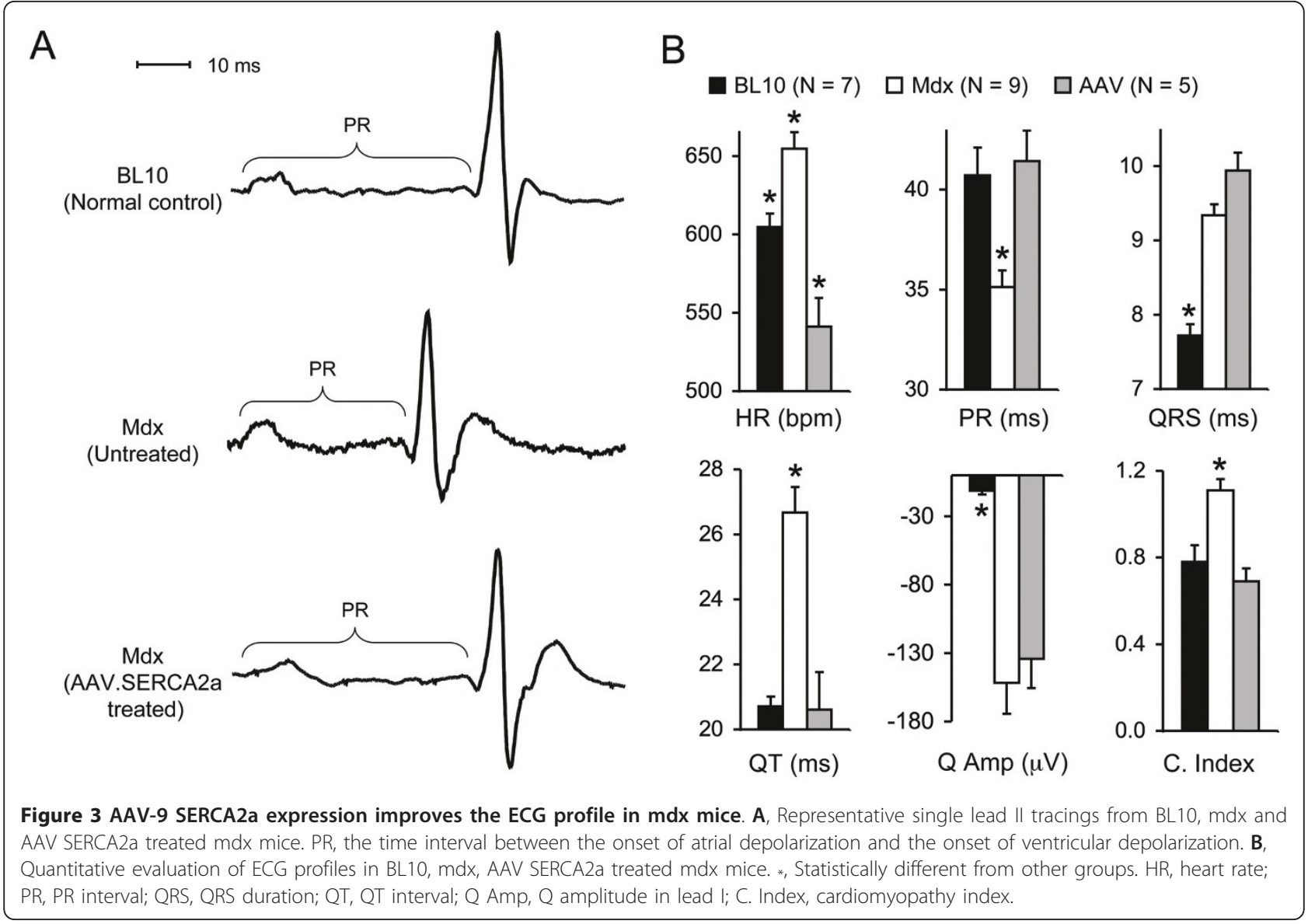

represent a significant barrier [37]. Alternative strategies based on endogenous genes may offer immune advantages compared to dystrophin replacement/repair therapies.

Over the last decade tremendous progress has been made in our understanding of the pathogenesis of DMD cardiomyopathy. An emerging theme is the disruption of calcium homeostasis (reviewed in [38,39]). First, stress-induced calcium influx is significantly increased in mdx cardiomyocytes. Extracellular calcium may enter through stretch-activated calcium channel (such as TRPC1), sarcolemmal microrupture and sodium-calcium exchanger $[4,40,41]$. Second, calcium may leak from the sarcoplasmic reticulum via phosphorylated and/or Snitrosylated ryanodine receptor $2[5,6]$. Collectively, these studies suggest that calcium overloading may represent a major pathogenic mechanism in DMD heart disease. Since SERCA2a plays a major role in calcium removal in the heart, we reasoned that forced expression of SERCA2a via AAV gene transfer might benefit dystrophin-deficient heart. We observed AAV genome persistence and SERCA2a over-expression in the hearts of 20-m-old mdx mice that were treated at age of 12 months (Figure 1). In support of our hypothesis, the
ECG profile was significantly improved in AAV SERCA2a treated mice (Figure 3).

AAV SERCA2a therapy has successfully reversed cardiac dysfunction in several large animal models $[17,30]$. A Phase I trial has revealed an excellent safety profile $[18,19]$. Recently released results from the Phase II trail have further established clinical efficacy of AAV SERCA2a therapy in treating advanced heart failure [31]. While additional in vitro analysis of myocardial contractility and in vivo evaluation of hemodynamics (echocardiography and cardiac catheter) are needed [42], our results demonstrate for the first time that AAV SERCA2a may hold great promise in alleviating cardiac disease in DMD patients. Consistent with our findings in the heart, a recent study suggests that AAV SERCA2a also significantly reduced skeletal muscle disease in dystrophic mice following local gene transfer [43].

\section{Conclusions}

Our results here have opened a new avenue to treat DMD cardiomyopathy using AAV SERCA2a gene delivery. Future studies in aged mdx mice, dystrophin/utrophin double knockout mice and dystrophin-deficient 
dogs may further validate AAV SERCA2a mediated gene therapy for DMD.

\section{List of abbreviations}

AAV: adeno-associated virus; BL10: C57BI/10; CFTR: cystic fibrosis transmembrane conductance regulator; CMV: cytomegalovirus; DMD: Duchenne muscular dystrophy; ECG: electrocardiography; HE: hematoxylin and eosin; PCR: polymerase chain reaction; SERCA2: cardiac isoform of sarcoplasmic reticulum calcium ATPase; vg: viral genome.

\section{Acknowledgements and Funding}

This work was supported by grants from the National Institutes of Health (DD, HL91883; and RH) and the Muscular Dystrophy Association (DD). We thank Lauren Vince and Keqing Zhang for technical help.

\section{Author details}

'Department of Molecular Microbiology and Immunology, School of Medicine, The University of Missouri, Columbia, MO, USA. '2Department of Cardiology, Cardiovascular Research Center, Mount Sinai School of Medicine, New York, NY, USA.

\section{Authors' contributions}

BB participated in ECG assay. DD conceived of study and wrote the manuscript. JS performed PCR, western blot, immunostaining, histology and ECG assay. RH provided critical reagents and advice. YY made AAV vector and participated in morphology and ECG studies. All authors read and approved the final manuscript.

\section{Competing interests}

Dr. Hajjar has ownership interest (include stock options and rights in patents) in Celladon Corporation, a company involved in SERCA2a clinical trials. The other authors declare that they have no competing interest.

\section{Received: 6 April 2011 Accepted: 11 August 2011}

Published: 11 August 2011

\section{References}

1. Shin J-H, Bostick B, Yue Y, Duan D: Duchenne cardiomyopathy gene therapy. In Muscle gene therapy. Edited by: Duan D. New York: Springer Science + Business Media, LLC; 2010:141-162.

2. Dunn JF, Radda GK: Total ion content of skeletal and cardiac muscle in the mdx mouse dystrophy: Ca2+ is elevated at all ages. J Neurol Sci 1991, 103:226-231.

3. Alloatti G, Gallo MP, Penna C, Levi RC: Properties of cardiac cells from dystrophic mouse. J Mol Cell Cardiol 1995, 27:1775-1779.

4. Williams IA, Allen DG: Intracellular calcium handling in ventricular myocytes from mdx mice. Am J Physiol Heart Circ Physiol 2007, 292: H846-855.

5. Fauconnier J, Thireau J, Reiken S, Cassan C, Richard S, Matecki S, Marks AR, Lacampagne A: Leaky RyR2 trigger ventricular arrhythmias in Duchenne muscular dystrophy. Proc Natl Acad Sci USA 2010, 107:1559-1564.

6. Sarma S, Li N, van Oort RJ, Reynolds C, Skapura DG, Wehrens XH: Genetic inhibition of PKA phosphorylation of RyR2 prevents dystrophic cardiomyopathy. Proc Natl Acad Sci USA 2010, 107:13165-13170.

7. Frank KF, Bolck B, Erdmann E, Schwinger RH: Sarcoplasmic reticulum Ca2 +-ATPase modulates cardiac contraction and relaxation. Cardiovasc Res 2003, 57:20-27.

8. Kawase Y, Hajjar RJ: The cardiac sarcoplasmic/endoplasmic reticulum calcium ATPase: a potent target for cardiovascular diseases. Nat Clin Pract Cardiovasc Med 2008, 5:554-565.

9. Lipskaia L, Chemaly ER, Hadri L, Lompre AM, Hajjar RJ: Sarcoplasmic reticulum $\mathrm{Ca}(2+)$ ATPase as a therapeutic target for heart failure. Expert Opin Biol Ther 2010, 10:29-41.

10. Rohman MS, Emoto N, Takeshima Y, Yokoyama M, Matsuo M: Decreased mAKAP, ryanodine receptor, and SERCA2a gene expression in $\mathrm{mdx}$ hearts. Biochem Biophys Res Commun 2003, 310:228-235.

11. Ghosh A, Yue Y, Shin J-H, Duan D: Systemic trans-splicing AAV delivery efficiently transduces the heart of adult mdx mouse, a model for Duchenne muscular dystrophy. Hum Gene Ther 2009, 20:1319-1328.
12. Bostick B, Yue Y, Lai Y, Long C, Li D, Duan D: Adeno-associated virus serotype-9 microdystrophin gene therapy ameliorates electrocardiographic abnormalities in mdx mice. Hum Gene Ther 2008 19:851-856.

13. Bostick B, Shin J-H, Yue Y, Duan D: AAV-microdystrophin therapy improves cardiac performance in aged female mdx mice. Mol Ther 2011, online publication on August 2 2011. doi:10.1038/mt.2011.154.

14. Bostick B, Yue $Y$, Duan D: Gender influences cardiac function in the $\mathrm{mdx}$ model of Duchenne cardiomyopathy. Muscle Nerve 2010, 42:600-603.

15. Bostick B, Yue Y, Long C, Duan D: Prevention of Dystrophin-Deficient Cardiomyopathy in Twenty-One-Month-Old Carrier Mice by Mosaic Dystrophin Expression or Complementary Dystrophin/Utrophin Expression. Circ Res 2008, 102:121-130.

16. Sakata S, Lebeche D, Sakata N, Sakata Y, Chemaly ER, Liang LF, Tsuji T, Takewa Y, del Monte F, Peluso R, Zsebo K, Jeong D, Park WJ, Kawase Y, Hajjar RJ: Restoration of mechanical and energetic function in failing aortic-banded rat hearts by gene transfer of calcium cycling proteins. $J$ Mol Cell Cardiol 2007, 42:852-861.

17. Kawase $Y$, Ly HQ, Prunier F, Lebeche D, Shi Y, Jin H, Hadri L, Yoneyama R, Hoshino K, Takewa Y, Sakata S, Peluso R, Zsebo K, Gwathmey JK, Tardif JC, Tanguay JF, Hajjar RJ: Reversal of cardiac dysfunction after long-term expression of SERCA2a by gene transfer in a pre-clinical model of heart failure. J Am Coll Cardiol 2008, 51:1112-1119.

18. Hajjar RJ, Zsebo K, Deckelbaum L, Thompson C, Rudy J, Yaroshinsky A, Ly H, Kawase Y, Wagner K, Borow K, Jaski B, London B, Greenberg B, Pauly DF, Patten $R$, Starling R, Mancini D, Jessup M: Design of a phase $1 / 2$ trial of intracoronary administration of AAV1/SERCA2a in patients with heart failure. J Card Fail 2008, 14:355-367.

19. Jaski BE, Jessup ML, Mancini DM, Cappola TP, Pauly DF, Greenberg B, Borow K, Dittrich H, Zsebo KM, Hajjar RJ: Calcium upregulation by percutaneous administration of gene therapy in cardiac disease (CUPID Trial), a first-in-human phase 1/2 clinical trial. J Card Fail 2009, 15:171-181.

20. Ghosh A, Yue Y, Long C, Bostick B, Duan D: Efficient whole-body transduction with trans-splicing adeno-associated viral vectors. Mol Ther 2007, 15:750-755.

21. Bostick B, Ghosh A, Yue Y, Long C, Duan D: Systemic AAV-9 transduction in mice is influenced by animal age but not by the route of administration. Gene Ther 2007, 14:1605-1609.

22. Lai Y, Yue Y, Liu M, Ghosh A, Engelhardt JF, Chamberlain JS, Duan D: Efficient in vivo gene expression by trans-splicing adeno-associated viral vectors. Nat Biotechnol 2005, 23:1435-1439.

23. Xu Z, Yue Y, Lai Y, Ye C, Qiu J, Pintel DJ, Duan D: Trans-splicing adenoassociated viral vector-mediated gene therapy is limited by the accumulation of spliced mRNA but not by dual vector coinfection efficiency. Hum Gene Ther 2004, 15:896-905.

24. Duan D, Yue Y, Zhou W, Labed B, Ritche TC, Grosschedl R, Engelhardt JF: Submucosal Gland Development in the Airway is Controlled by Lymphoid Enhancer Binding Factor-1 (Lef-1). Development 1999, 126:4441-4453.

25. Bostick B, Yue Y, Long C, Marschalk N, Fine DM, Chen J, Duan D: Cardiac expression of a mini-dystrophin that normalizes skeletal muscle force only partially restores heart function in aged Mdx mice. Mol Ther 2009, 17:253-261.

26. Hadri L, Bobe $R$, Kawase $Y$, Ladage $D$, Ishikawa $K$, Atassi F, Lebeche D, Kranias EG, Leopold JA, Lompre AM, Lompré AM, Lipskaia L, Hajjar RJ: SERCA2a gene transfer enhances eNOS expression and activity in endothelial cells. Mol Ther 2010, 18:1284-1292.

27. Yue Y, Liu M, Duan D: C-terminal truncated microdystrophin recruits dystrobrevin and syntrophin to the dystrophin-associated glycoprotein complex and reduces muscular dystrophy in symptomatic utrophin/ dystrophin double knock-out mice. Mol Ther 2006, 14:79-87.

28. Bostick B, Yue Y, Duan D: Phenotyping cardiac gene therapy in mice. Methods Mol Biol 2011, 709:91-104.

29. Duan D: Challenges and opportunities in dystrophin-deficient cardiomyopathy gene therapy. Hum Mol Genet 2006, 15(Spec No 2): R253-261.

30. Beeri R, Chaput M, Guerrero JL, Kawase Y, Yosefy C, Abedat S, Karakikes I, Morel C, Tisosky A, Sullivan S, Handschumacher MD, Gilon D, Vlahakes GJ, Hajjar RJ, Levine RA: Gene delivery of sarcoplasmic reticulum calcium ATPase inhibits ventricular remodeling in ischemic mitral regurgitation. Circ Heart Fail 2010, 3:627-634. 
31. Jessup M, Greenberg B, Mancini D, Cappola T, Pauly DF, Jaski B, Yaroshinsky A, Zsebo KM, Dittrich H, Hajjar RJ: Calcium Upregulation by Percutaneous Administration of Gene Therapy in Cardiac Disease (CUPID): A Phase 2 Trial of Intracoronary Gene Therapy of Sarcoplasmic Reticulum Ca2+-ATPase in Patients With Advanced Heart Failure. Circulation 2011, 124:304-313.

32. Divet A, Lompre AM, Huchet-Cadiou C: Effect of cyclopiazonic acid, an inhibitor of the sarcoplasmic reticulum Ca-ATPase, on skeletal muscles from normal and mdx mice. Acta Physiol Scand 2005, 184:173-186.

33. Kaspar RW, Allen HD, Montanaro F: Current understanding and management of dilated cardiomyopathy in Duchenne and Becker muscular dystrophy. J Am Acad Nurse Pract 2009, 21:241-249.

34. Yue Y, Li Z, Harper SQ, Davisson RL, Chamberlain JS, Duan D:

Microdystrophin Gene Therapy of Cardiomyopathy Restores DystrophinGlycoprotein Complex and Improves Sarcolemma Integrity in the Mdx Mouse Heart. Circulation 2003, 108:1626-1632.

35. Townsend D, Blankinship MJ, Allen JM, Gregorevic P, Chamberlain JS, Metzger JM: Systemic Administration of Micro-dystrophin Restores Cardiac Geometry and Prevents Dobutamine-induced Cardiac Pump Failure. Mol Ther 2007, 15:1086-1092.

36. Wu B, Moulton HM, Iversen PL, Jiang J, Li J, Spurney CF, Sali A, Guerron AD, Nagaraju K, Doran T, Lu P, Xiao X, Lu QL: Effective rescue of dystrophin improves cardiac function in dystrophin-deficient mice by a modified morpholino oligomer. Proc Natl Acad Sci USA 2008, 105:14814-14819.

37. Mendell JR, Campbell K, Rodino-Klapac L, Sahenk Z, Shilling C, Lewis S, Bowles D, Gray S, Li C, Galloway G, Malik V, Coley B, Clark KR, Li J, Xiao X, Samulski J, McPhee SW, Samulski RJ, Walker CM: Dystrophin immunity in Duchenne's muscular dystrophy. N Engl J Med 2010, 363:1429-1437.

38. Constantin B, Sebille S, Cognard C: New insights in the regulation of calcium transfers by muscle dystrophin-based cytoskeleton: implications in DMD. J Muscle Res Cell Motil 2006, 27:375-386.

39. Allen DG, Gervasio OL, Yeung EW, Whitehead NP: Calcium and the damage pathways in muscular dystrophy. Can J Physiol Pharmacol 2010 88:83-91.

40. Yasuda S, Townsend D, Michele DE, Favre EG, Day SM, Metzger JM: Dystrophic heart failure blocked by membrane sealant poloxamer. Nature 2005, 436:1025-1029.

41. Fanchaouy M, Polakova E, Jung C, Ogrodnik J, Shirokova N, Niggli E: Pathways of abnormal stress-induced $\mathrm{Ca} 2+$ influx into dystrophic $\mathrm{mdx}$ cardiomyocytes. Cell Calcium 2009, 46:114-121.

42. Janssen PM, Hiranandani N, Mays TA, Rafael-Fortney JA: Utrophin deficiency worsens cardiac contractile dysfunction present in dystrophin-deficient mdx mice. Am J Physiol Heart Circ Physiol 2005, 289: H2373-2378.

43. Goonasekera SA, Lam CK, Millay DP, Sargent MA, Hajijar RJ, Kranias EG, Molkentin JD: Mitigation of muscular dystrophy in mice by SERCA overexpression in skeletal muscle. J Clin Invest 2011, 121:1044-1052.

doi:10.1186/1479-5876-9-132

Cite this article as: Shin et al.: SERCA2a gene transfer improves electrocardiographic performance in aged mdx mice. Journal of Translational Medicine 2011 9:132.

\section{Submit your next manuscript to BioMed Central and take full advantage of:}

- Convenient online submission

- Thorough peer review

- No space constraints or color figure charges

- Immediate publication on acceptance

- Inclusion in PubMed, CAS, Scopus and Google Scholar

- Research which is freely available for redistribution

Submit your manuscript at www.biomedcentral.com/submit
Biomed Central 